NBER WORKING PAPER SERIES

BUT THEY DON'T WANT TO REDUCE HOUSING EQUITY

Steven F. Venti

David A. Wise

Working Paper No. 2859

NATIONAL BUREAU OF ECONOMIC RESEARCH

1050 Massachusetts Avenue

Cambridge, MA 02138

February 1989

Financial support for this research was provided by the National Institute on Aging grani number P0lAG05842. This paper is part of NBER's research program in Aging. Any opinions expressed are those of the authors not those of the National Bureau of Economic Research. 
NBER Working Paper \#2859

February 1989

\section{BUT THEY DON'T WANT TO REDUCE HOUSING EQUITY}

\section{ABSTRACT}

The majority of the wealth of most elderly is in the form of housing equity. It is often claimed that many elderly would transfer wealth from housing to finance current consumption expenditure, were it not for the large transaction costs associated with changes in housing equity. This is the rationale for a market in reverse annuity mortgages. This paper considers whether transaction costs, understood to include the psychic costs associated with leaving friends, family surroundings, and the like, prevent the elderly from making choices that would improve their financial circumstances. The analysis considers jointly the probability that an elderly family will move and the housing equity that is chosen when a move occurs. The results are based on the decisions of the Retirement History Survey sample between 1969 and 1979. Relative to the potential gains from a reallocation of wealth between housing equity and other assets, transaction costs are very large. Nonetheless, the effect on the housing equity of the elderly is very small. On balance, were all elderly to move and choose optimum levels of housing equity, the amount of housing equity would be increased slightly. Most elderly are not liquidity constrained. And contrary to standard formulations of the life cycle hypothesis, the typical elderly family has no desire to reduce housing equity. The desired reduction of housing equity is largest among families with low income and high housing wealth, but even in this case the desired reductions are rather small. And these desired reductions are more than offset by the desired increases of other families, especially those with high income and low housing wealth. Thus, consistent with the previous findings of Venti and Wise and of Feinstein and McFadden, limited demand may explain the absence of a market for reverse annuity mortgages.

Steven $F$. Venti

Department of Economics

Dartmouth College

Hanover, NH 03755
David A. Wise

Kennedy School of Government

Harvard University

Cambridge, MA 02138 
BUT THEY DON'T WANT TO REDUCE HOUSING EQUITY

by

Steven F. Venti and David A. Wise ${ }^{\star}$

The majority of the wealth of most elderly is in the form of housing equity. This housing wealth, it is claimed, is a potential source of support for the elderly as they age. It is further claimed that many elderly would choose to transfer wealth from housing to finance current consumption expenditure, were it not for the large transaction costs associated with changes in housing equity. In the past, it has typically been necessary for such families to move to withdraw wealth from housing. Indeed, the rational for a market in reverse annuity mortgages has been that the elderly would like to withdraw wealth from housing were it possible to do so without incurring the large transaction costs associated with moving. This paper considers whether these claims are correct. Two related questions are addressed:

- Given the predetermined financial and other circumstances of families as they approach retirement ages, would the typical elderly family like to withdraw wealth from housing?

- Are the transaction costs of moving large, and do they constrain adjustments in the housing wealth of the elderly as they age?

The paper provides a clear answer to the first question. Were all elderly to choose optimal housing equity, given their existing circumstances, there would be little change in housing wealth on average. In particular, the typical elderly family would not choose to reduce housing equity. The answer

*We wish to thank Alan Auerbach for his comments as the disucssanr, some of which are now incorporated in the paper. 
to the second question is less evident. Assuming that the elderly could gain from a reallocation of wealth between housing equity and other assets, the relative gain, in these terms, necessary to justify moving is typically very large. Our evidence suggests a strong preference for remaining in existing housing as the elderly grow older. On the other hand, that the housing equity of the elderly is not typically reduced as they age is not explained by the high transaction costs of moving. The elderly like it that way.

In a predecessor to this paper [1987], we considered the change in housing equity when the elderly move. The primary conclusion of that analysis was that the elderly who move were about as likely to increase as to decrease housing equity. But, families with low income relative to housing wealth were more likely to move and to reduce housing equity when they did. The latter finding raises the possibility that transaction costs constrained the choices of some elderly who otherwise would have chosen to transfer wealth out of housing. 1

The current paper is a more formal treatment of moving and the choice of housing equity; the two are considered jointly. The method is analogous to the approach set forth in Venti and Wise [1984] and used to analyze the housing choices of low income renters. The current paper considers the allocation of bequeathable wealth between housing and other assets, conditional on their predetermined levels and on the income and other circumstances of the elderly as they age. There are two key features of the


Feinstein and McFadden [1988], based on the Panel Survey of Income Dynamics; our findings were based on the Retirement History Survey. These findings are also consistent with the results reported earlier by Merrill [1984]. 
model: one is that an elderly family moves if the gain from changing housing outweighs the transaction costs of moving. Transaction costs are understood to include, and are likely to be dominated by, the psychic costs associated with leaving friends, familiar surroundings, and the like. The other is that the housing equity chosen after a move represents the optimal level of housing equity, given current circumstances. Based on the second assumption, the model is used to simulate the changes in housing equity that the elderly would choose to make, were they to overcome the transaction costs of moving and choose optimal levels of housing equity. The analysis is based on the Retirement History Survey (RHS). Families are followed over the six RHS surveys, conducted every two years between 1969 and 1979.

The model is described in the first section. Parameter estimates are discussed in section two and the results of simulations are reported in the third section. Section four contains concluding remarks.

\section{The Mode1}

The goal of the analysis is to estimate the housing equity that the elderly would prefer. With this goal in mind, we consider the allocation of bequeathable wealth between housing and other assets, conditional on current income and other circumstances. Suppose that the value of housing equity versus other wealth can be captured by the simple function

(1) $\quad \mathrm{V}=\mathrm{H}^{\beta}(\mathrm{w}-\mathrm{H})^{1-\beta}$

where $H$ is housing equity, $W$ is total bequeathable wealth, and $\beta$ is a preference parameter depending on income and other individual characteristics. Then preferred housing equity is 
(2)

$$
H-\beta W
$$

In fact, the precise functional form of (2), described below, was chosen to fit housing equity choices. Equation ( 1 ) was then chosen to be consistent with these empirically observable outcomes. ${ }^{2}$ It essentially serves to compare existing housing equity with the preferred level and as a device to assure consistent treatment of moving and housing equity choices.

The family moves between two survey periods if

$$
\frac{v_{*}}{v_{0} \cdot M}>1 \text {, }
$$

where $V_{*}$ is the value of the optimal allocation of wealth, $V_{0}$ is the value of the allocation at the beginning of the period, and $M$ indicates the preference for current housing, presumably with a value greater than one. It reflects the transaction costs that must be overcome if the family is to move. If the gain from moving is $G$, the family will move if

$$
G=\operatorname{lnV} V_{\star}-\operatorname{lnV} V_{0}-\ln \mathbb{M}>0
$$

The transaction costs parameter $M$ reflects everything that gives an advantage to current housing, after controlling for the equity value of housing and the wealth allocation that it represents. ${ }^{3}$ For example, the value

${ }^{2}$ More "structural" specifications based on the asset value and the consumption value of housing, and on a budget constraint limiting the user cost of housing to current income, were rejected in favor of this simple specification.

${ }^{3}$ In this sense, the model is consistent with models explicitly incorporating both consumption and investment demands for housing, as in Henderson and Ioannides [1983, 1987], for example. 
function in equation ( 1 ) could have been written with an additional multiplicative term $E^{\alpha}$, where $E$ represents attributes that accompany housing, in addition to its equity value. Then $\Delta \operatorname{lnV}$ would include a term $\alpha\left(\ln E_{\star}\right.$ $\ln E_{0}$ ), which would be part of what $\operatorname{lnM}$ is presumed to capture.

Transaction costs $M$ are parameterized as

$$
\ln M=m_{0}+m(X)+e,
$$

where $\mathbb{m}_{0}$ is a constant term, $m(X)$ is a function of individual characteristics like change in marital status or retirement, and $e$ is a random term. The random term is assumed to have the variance components form

$$
e_{i t}=\lambda_{i}+\epsilon_{i t}, \quad \operatorname{var}(\lambda)-\sigma_{\lambda}^{2}, \quad \operatorname{var}(\epsilon)=\sigma_{\epsilon}^{2},
$$

where $\lambda_{i}$ reflects variation among individuals in resistance to or preference for moving. It is clear that families could move for many reasons other than to change housing equity and that the value of the house to the family reflects much more than its asset value. It is also clear that many family attributes that may determine moving decisions are not included explicitiy in our analysis. ${ }^{4}$ Thus the individual-specific term $\lambda$, that is assumed to persist over time. The $\epsilon_{i t}$ component is assumed to be random across survey intervals and to be uncorrelated with $\lambda$. For any family, it captures the effect of changes in unmeasured variables from interval to interval. As will become clear below, it may also reflect the effect of the difference between

${ }^{4}$ In their work, Feinstein and McFadden strongly reject the nuil hypothesis of no unobserved household effects on mobility decisions. 
actual alternative housing possibilities that exist in fact, and the optimal choice that is assumed to exist.

If $\epsilon$ has a normal distribution with mean zero, the probability that the family will move between any two survey periods, conditional on $\lambda$, is

$$
\begin{aligned}
\operatorname{Pr}[\text { Yove }] & =\operatorname{Pr}\left[\varepsilon<\Delta \ln V-\mathrm{m}_{0}-\mathrm{m}(\mathrm{X})-\lambda\right] \\
& =\Phi\left[\left(\Delta \ln \mathrm{V}-\mathrm{m}_{0}-\mathrm{m}(\mathrm{X})-\lambda\right) / \sigma_{\epsilon}\right]
\end{aligned}
$$

where $\Delta \operatorname{lnV}=1 n V_{\star}-1 n V_{0}$ and $\Phi$ is the cumulative normal distribution function. The term $\Delta \mathrm{lnV}$ is a measure of disequilibrium; it is large if the optimal allocation of wealth between housing and other assets is very different from the existing allocation. The optimal allocation, however, is likely to vary among families. To capture potential differences among families in preferences for housing equity, $\beta$ is parameterized as

$$
\beta_{t}=\beta_{t-1}+\mathrm{d}(z)+\nu, \quad \mathrm{E}(\nu)=0, \quad \operatorname{var}(\nu)=\sigma_{\nu}^{2} .
$$

That is, $\beta$ is assumed to follow a random walk with drift $d(Z)$, where

$$
d(Z)=d_{0}+d_{1} A+d_{2} A^{2}+d_{3} Y+d_{4} W+d_{5} Y \cdot W
$$

Here, the terms in age A capture the effect of age on the drift, reflecting the possibility that preferences change with age. The terms in income $Y$ are to recognize that the amount of total wealth that the family prefers to have in housing equity is likely to depend on current income, which along with nonhousing bequeathable wealth can be used to finance current consumption. The disturbance $\nu$ reflects random changes in preferences not captured by measured variables.

The allocation of wealth at the beginning of the period is taken as a base indication of preferences, and optimal choices are considered relative to 
that base. In period $t-1$, we observe $H_{t-1}$ and $W_{t-1}$; we set $\beta_{t-1}-H_{t-1} / W_{t-1}$. esired housing in period $t$ is then given by an estimate based on the oroportion of total wealth allocated to housing in period t-1, plus a leviation from that estimate. As the family ages, there may be an increasingly large difference between $\mathrm{H}_{t-1} / w_{t-1}$ and desired $\beta_{t}$, the extent of disequilibrium may increase. The term $d(z)$ reflects this possibility. In effect, the housing demand equation predicts desired changes in housing equity. Based on equations ( 8$)-(9)$ and the definitions above, it is given by

$$
\mathrm{H}_{t}-\left(\mathrm{H}_{t} / \mathrm{w}_{t-1}\right) \mathrm{w}_{t}+(\mathrm{d}(\mathrm{z})) \mathrm{w}_{t}+\mathrm{w}_{t}
$$

The information to estimate this equation comes primarily from the changes in housing equity for families who move during the survey period. In essence, the model estimates the preferred change in housing equity as a function of age, current income, and cirrent total wealth. ${ }^{5}$

The random term $\nu$ may be interpreted in two ways: one is as a maximization error, reflecting for example an inability to find a house with precisely the optimal value. The other is as a further indication of heterogeneity among families, reflecting desired housing choices. The implications of both interpretations are considered below.

${ }^{5}$ It is clear from equation (10) that the specification may be interpreted as a disequilibrium model, where $d(Z)$ represents the extent of disequilibrium in the proportion of wealth allocated to housing. An alternative procedure is to predict desired housing wealth directly as a function of age, current income, and total wealth, without incorporating the term $\mathrm{H}_{t-1} / \mathrm{W}_{t-1}$. The use of the predetermined ratio is a way to control directly for heterogeneity; otherwise it would be concentrated to a greater extent in the disturbance term. Because the estimation procedure does not integrate over possible values of desired housing equity, given the right-hand variables in equation (10), more accurate predictions can be had by using the procedure that is followed here. 
The data consist of five surveys conducted at 2 -year intervals. There are two possible outcomes for each family: 1. The family does not move during the entire 10-year survey period. 2. The family moves in period $t$ and chooses a level of housing equity $\mathrm{H}_{\tau}$. The probability of the first outcome is given by

$$
\operatorname{Pr}\left[\text { Don't }^{\prime} \text { move }\right]-\int_{\lambda}\left[1-\Phi_{1}\right] \ldots\left[1-\Phi_{5}\right] \mid f(\lambda) \mathrm{d} \lambda
$$

where is defined in equation (7), the subscripts indicate intervals between successive surveys, and $f(\lambda)$ is the density of $\lambda$. The probability of the second outcome is given by

$$
\begin{aligned}
& \operatorname{Pr}\left[\text { Move between } \tau-1 \text { and } \tau \text {, and spend } H_{\tau}\right] \\
& \quad=\left(\int_{\lambda}\left\{\left[1-\Phi_{1}\right] \ldots\left[1-\Phi_{\tau-1}\right] \Phi_{\tau} \mid f(\lambda) \mathrm{d} \lambda\right] \cdot g\left(\mathrm{H}_{\tau}\right)\right.
\end{aligned}
$$

where $\mathrm{g}\left(\mathrm{H}_{\tau}\right)$ is the density of desired housing equity in period $\tau$. Given the family-specific term $\lambda_{i}$, the probability of moving during the ten-year period of the RHS is given by the product of univariate normal probabilities, each representing the mobility decision for a two-year interval. Integrating over possible values of $\lambda_{i}$ is accomplished by Gaussian quadrature. ${ }^{6}$ In calculating the probability that the family moves, the terms $\operatorname{lnv}_{\star t}$ and $\operatorname{lnV}_{0 t}$ must be evaluated. The first term represents the value of the optimal wealth allocation and is given by $\operatorname{lnv}_{\star t}-\beta_{t} \operatorname{lnH}_{\star t}+\left(1-\beta_{t}\right) \ln \left(\mathrm{W}_{t}-\mathrm{H}_{\star t}\right)$, where $\mathrm{H}_{* t}-\beta_{t} \mathrm{~W}_{t}$. The second term is the value of the wealth allocation inherited

${ }^{6}$ See Butler and Moffit [1982] for more explanation in the context of a different application. 
rom the previous period and is given by $\operatorname{lnv}_{0 t}-\beta_{t} 1 n H_{t-1}+\left(1-\beta_{t}\right) \ln \left(W_{t}-H_{t-1}\right) .7$

In summary: Families are followed until they move (or until 1979 when he RHS panel survey ended). It is assumed that the optimal level of housing. quity $\mathrm{H}_{\star t}$ is chosen when the family moves, up to an error component epresented by $\nu$. The family moves if the gain from moving outweighs the ransaction costs of moving. The predicted level of $\mathrm{H}_{\star t}$ is used to determine he value of preferred housing equity in period $t$; the value of current lousing equity is determined by the level of housing equity at the beginning f the interval, $v_{0, t}$. Heterogeneity in resistance to moving, or in attachment to current housing, is represented by a random term with a variance omponents decomposition. The family-specific component $\lambda_{i}$ is assumed to be he same, for a given family, over the period of the analysis. The timerarying component is $\epsilon_{i t}$. The family moves between period $t-1$ and $t$ if $t_{t}=\operatorname{lnV_{\star t}} \cdot \operatorname{lnV_{0t}} \cdot \mathrm{m}_{0}-m\left(\mathrm{x}_{t}\right)>\lambda_{i}+\epsilon_{i t}$. The disturbance terms $\nu, \lambda_{i}, \epsilon_{i t}$ and are assumed to be mutually uncorrelated.

\section{Parameter Estimates}

Estimates are based on data from the Retirement History Survey (RHS). The survey covered families headed by persons age 58 to 63 in 1969. The

${ }^{7}$ In principle, both probabilities might involve integration over possible ralues of $H_{\star r}$, since not all families have the same preferences and even if they did, the optimal housing.level may not be available at any point in time. [ntegration would be over the random term $\nu$, when $\nabla_{\star}$ is evaluated. This is the procedure followed in Venti and Wise [1984]. It is not done here for two ceasons. It adds substantial complexity to the likelihood calculations. And, the method used to predict desired $\mathrm{H}_{t}$ already incorporates substantial neterogeneity in housing preferences; the remaining residual variance is small. 
families were interviewed every two years between 1969 and 1979; there were six waves altogether. The final sample is comprised of 3423 families. Of these, 24 percent moved during the 1969-1979 period. Selection of the estimation sample is explained in an appendix. Estimates of the parameters in the model are shown in table 1 . The estimated housing equity function is discussed first, then the probability of moving.

\section{A. Housing Equity}

The disturbance term in the housing equity function is heteroskedastic, with the specification $\sigma_{\nu} W$. The estimated $\sigma_{\nu}$ is 0.2008 ; the mean of $W$ is $\$ 74,465$. Thus, given the ratio of housing wealth to total wealth in the last period, current income, current wealth, and age, the standard deviation of the desired change in housing equity is $\$ 14,953$, evaluated at the mean of wealth. The mean difference between desired and actual equity is small, however, about $\$ 1010$, estimated over the whole sample. This means that on average the gain to be had by a reallocation of wealth between housing and other assets is small. The mean of the estimated values of $\Delta 1 \mathrm{nV}$ is only .041, indicating that the average potential gain, in utility terms, from a reallocation of wealth is only about 4 percent. It is substantially larger than that for some families, however. The standard deviation of the estimated $\Delta \operatorname{lnV}$ is .115.

The mean of the estimated values of $\beta$, the desired proportion of wealth in housing equity, is .53 . The mean of the estimated values of $d$, the difference between the curzent and the desired proportions is .0107 . Thus, on average, the desired proportion of wealth in housing equity is very close to the existing proportion.

There is essentially no effect of age on desired housing equity. As the typical family ages one year, the desired proportion of wealth in housing is 
Table 1. Parameter estimates.

Parameter

Estimate

Standard

Error

\section{Housing Equity:}

Disturbance variance, $\sigma_{\nu}$

0.2008

0.0077

Drift, $d(X)$

Constant

Age

Age squared $(/ 100)$

Income

Wealth

Income $x$ Wealth

$-2.6855$

0.1114

0.0859

0.0037

$-0.0682$

0.0031

0.0015

0.0001

$-0.0007$

0.0001

0.0001

0.0000

Moving:

Disturbance terms:
$\sigma_{\lambda}$
0.6197
0.0826
$\sigma_{\lambda}$
0.7710
0.0837

Transaction Costs, lnM:

Constant, $\mathrm{m}_{0}$

2.0039

0.1951

Retirement Status
No $\rightarrow$ No
Yes $\rightarrow$ No
$-0.3034$
0.1010
No $\rightarrow$ Yes
$-0.3810$
0.0580
Yes $\rightarrow$ Yes
$-0.2700$
0.0558

Family status

Single $\rightarrow$ Single

Married - $>$ Married

$-0.2846$

Change

$-0.5626$

0.0533

0.0896

Health Status

Same

Better

$-0.1728$

0.0496

Worse

0.0508

0.0407

Children

No

Yes

$-0.0269$

0.0554

Means and Standard deviations [ $\cdot]$ of estimated values:

Mean $\Delta$ lnv

0.0409

Mean $\ln M$

1.5578

Mean $\beta$

0.5255

Mean $\mathrm{d}$

0.0107

$[0.1152]$

[0.2180]

$[0.2213]$

$[0.0108]$

Log-likelihood:

$-3391.0$

Number of observations: 
reduced by -.0014: .0859-2(.000682)Age, evaluated at the mean age of 64 . The housing equity function fits the observed choices of movers very well, as shown in figure 1. The estimated values of $\beta$--the desired proportion of total wealth in housing equity, and the observed choices $H+W$, are graphed against total wealth percentile for movers. No systematic deviation of predicted from actual values is revealed.

\section{B. Moving}

Recall that the transaction costs parameter $M$ reflects everything that gives an advantage to current housing, after controlling for the equity value of housing and the wealth allocation that it represents.

It is informative first to report the results from a two-stage estimation procedure: the housing equity equation (11) is estimated by non-linear least squares in the first stage, using data for movers only. The prediction of desired housing equity from the first stage is used to calculate $\Delta \operatorname{lnv}$. A simple probit equation with $\Delta \ln V$ and other variables that are assumed to determine the probability of moving is estimated in the second stage. The relevant probabilities are of the form $\operatorname{Pr}[$ Move $]=\operatorname{Pr}[e<\Delta \operatorname{lnV}-1 \mathrm{nM}]$, where here e represents both the individual-specific and the period specific random components of moving, $e=\lambda+\epsilon$. The larger $\Delta 1 \mathrm{nV}$, the greater the probability of moving, as expected. ${ }^{8}$ But $\Delta 1 \mathrm{nV}$ explains only a small part of moving behavior. With no change in retirement, marital, or health status, the transaction costs parameter $1 \mathrm{nM}$, which is the constant term in the probit equation, is large, say on the order of 1.5 . Because $\Delta \ln v$ explains so little

${ }^{8}$ In this specification, unlike the standard probit model, the error variance is in fact estimated by the coeficient on $\Delta 1 \mathrm{nV}$. 
Figure 1: Predleted va. Actual Values of HW by Tolal Woath Percentile

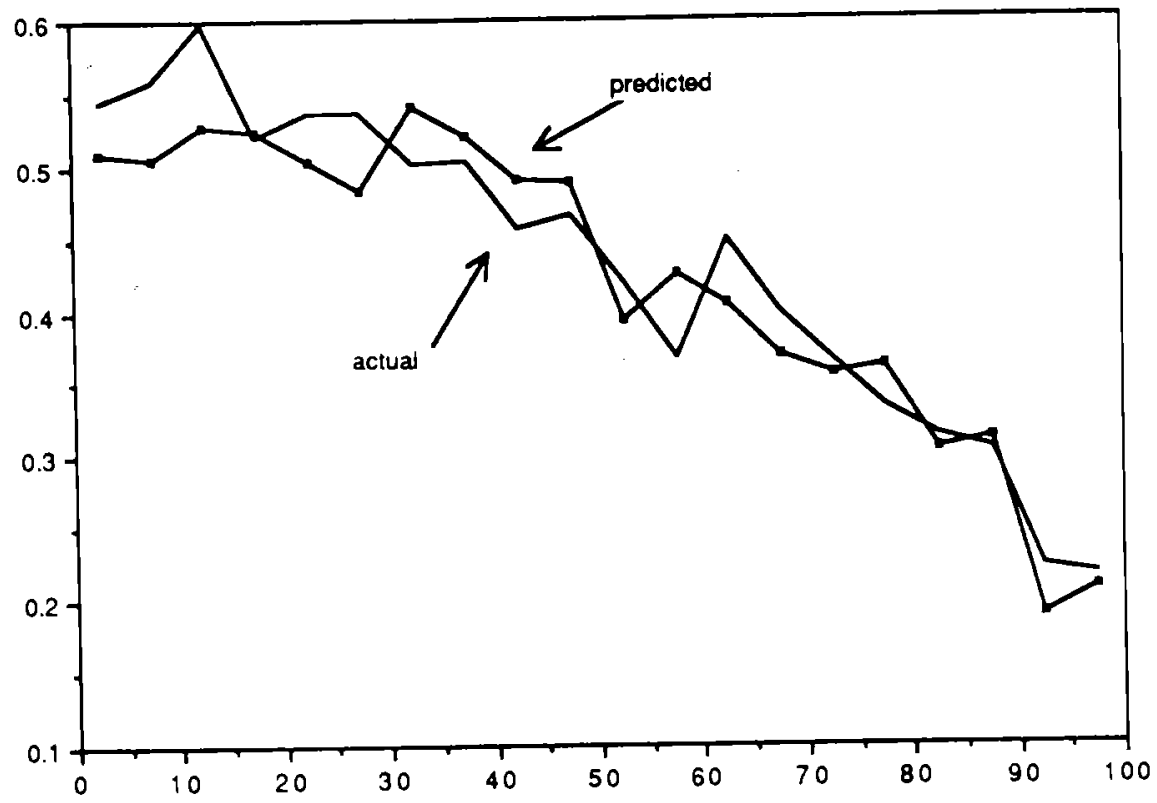

Total Wosith Percentile 
of moving behavior, the constant term must be large to yield the small probability of moving that the data exhibit. Thus the results from this procedure indicate that the value associated with housing equity, and the wealth allocation that it represents, must be increased substantially--about 50 percent-for a family to move. Indeed, without a change in family status or retirement, the "transaction costs" of moving are apparently prohibitive for many families, the family is simply not going to move. This is consistent with the small moving probability in any two year interval, about .08 on average .

Now consider the maximum likelihood estimates reported in table 1 . Three key parameters determine the estimated transaction costs: $\mathbb{m}_{0}$, estimated to be $2.00, \sigma_{\epsilon}$ estimated at 0.77 , and $\sigma_{\lambda}$ with an estimated value of 0.62 .9 The mean of the estimated values of $\mathrm{lnM}$ is 1.56 . Thus the estimates suggest a mean transaction costs parameter of 1.56 , with a standard deviation in any time interval of 1.39. For a few, then, the resistance to moving is very small if the estimates are taken lizerally; for many more the resistance is quite large. On average, the value associated with the allocation of total wealth would have to be increased by over 50 percent to induce the family to move.

Much more important than a potential reallocation of wealth-- $\ln V--$ in the decision to move are changes in retirement, marital, or health status. The probability of moving in the base case 10 is .075 . If the family head retires

${ }^{9}$ These estimated values are sensitive to errors in reported housing equity. If instead of the median of the several housing values reported by each family in the biannual surveys before a move (see the appendix), the actual recorded values are used, all of these estimates are considerably larger.

10 With $\Delta l n V$ evaluated at its mean and with all the dunny variables as sumed to be zero. 
during the interval, the probability is increased to .122. If there is a change in marital status--from married to divorced or from married to widowed for example--the probability increases to .150. ${ }^{11}$ A much larger proportion of families in these circumstances have very low transaction costs, by our definition, assuming the same disturbance variance. Families who otherwise would find moving extremely unattractive find that it is much less so at the time of these precipitating shocks.

\section{Simulat1ons}

There are two distinct questions about the desired reallocation of wealth among housing equity and other assets: one is the magnitude of the desired changes, the other is whether they are positive or negative. The magnitude of the desired changes is shown in tables $2 a$ and $2 b$. The entries in the tables are the average (and median) of the absolute values of the difference between actual and desired housing equity. For a given family, the comparison is made for each survey year until the family moves; thus a single family may contribute several observations. Actual housing equity is the value inherited from the previous period. To predict desired housing in table 2a, the disturbance term in the housing equity equation (10) is not considered; it is assumed to reflect maximization error. The overall average, including both movers and stayers is $\$ 5,377$. It is $\$ 9,886$ for movers, but only $\$ 5,117$ for stayers. The medians show comparable differences, but the magnitudes are reduced; the overall median is $\$ 2,315$; it is $\$ 5,159$ for movers and $\$ 2,195$

11 In fact divorce or marriage are associated with a much higher probability of moving, about .43. (See Venti and Wise [1987]). 
Table 2a. Mean (Median) of Absolute Values of Preferred Minus Actual Housing Equity, By Move Status and By Housing Equity :nd Income Quartiles, Excluding Disturbance Term.

\begin{tabular}{|c|c|c|c|c|c|}
\hline Income & \multicolumn{4}{|c|}{ Housing Equity } & Total \\
\hline \multicolumn{6}{|c|}{ A11 } \\
\hline Low & $\begin{array}{l}1734 \\
(660)\end{array}$ & $\begin{array}{c}3415 \\
(1685)\end{array}$ & $\begin{array}{c}4590 \\
(2244)\end{array}$ & $\begin{array}{c}8243 \\
(5384)\end{array}$ & $\begin{array}{c}3555 \\
(1360)\end{array}$ \\
\hline 2 nd & $\begin{array}{c}2569 \\
(1162)\end{array}$ & $\begin{array}{c}3663 \\
(2176)\end{array}$ & $\begin{array}{c}4918 \\
(2617)\end{array}$ & $\begin{array}{c}7844 \\
(4270)\end{array}$ & $\begin{array}{c}4503 \\
(2187)\end{array}$ \\
\hline $3 \mathrm{rd}$ & $\begin{array}{c}2888 \\
(1324)\end{array}$ & $\begin{array}{c}3742 \\
(2125)\end{array}$ & $\begin{array}{c}5155 \\
(2806)\end{array}$ & $\begin{array}{c}8285 \\
(4420)\end{array}$ & $\begin{array}{c}5054 \\
(2496)\end{array}$ \\
\hline 4 th & $\begin{array}{c}4052 \\
(1705)\end{array}$ & $\begin{array}{c}4317 \\
(2101)\end{array}$ & $\begin{array}{c}6409 \\
(3367)\end{array}$ & $\begin{array}{l}12394 \\
(6016)\end{array}$ & $\begin{array}{c}8396 \\
(3717)\end{array}$ \\
\hline Total & $\begin{array}{l}2435 \\
(963)\end{array}$ & $\begin{array}{c}3737 \\
(2020)\end{array}$ & $\begin{array}{c}5343 \\
(2815)\end{array}$ & $\begin{array}{c}9980 \\
(4996)\end{array}$ & $\begin{array}{c}5377 \\
(2315)\end{array}$ \\
\hline \multicolumn{6}{|c|}{ Movers } \\
\hline $\begin{array}{l}\text { Low } \\
\text { 2nd }\end{array}$ & $\begin{array}{c}3744 \\
(2233) \\
4526 \\
(2584)\end{array}$ & $\begin{array}{c}8899 \\
(6205) \\
6716 \\
(3598)\end{array}$ & $\begin{array}{c}8352 \\
(7861) \\
8328 \\
(5340)\end{array}$ & $\begin{array}{c}11060 \\
(11272) \\
16509 \\
(9264)\end{array}$ & $\begin{array}{c}7473 \\
(4932) \\
9062 \\
(4865)\end{array}$ \\
\hline $3 \mathrm{rd}$ & $\begin{array}{c}6883 \\
(3552)\end{array}$ & $\begin{array}{c}6156 \\
(3966)\end{array}$ & $\begin{array}{c}5707 \\
(4243)\end{array}$ & $\begin{array}{l}13064 \\
(8286)\end{array}$ & $\begin{array}{c}8099 \\
(4587)\end{array}$ \\
\hline 4th & $\begin{array}{c}8635 \\
(3187)\end{array}$ & $\begin{array}{c}8247 \\
(6314)\end{array}$ & $\begin{array}{l}10829 \\
(6008)\end{array}$ & $\begin{array}{c}20069 \\
(10189)\end{array}$ & $\begin{array}{l}14211 \\
(7171)\end{array}$ \\
\hline Total & $\begin{array}{c}5699 \\
(2707)\end{array}$ & $\begin{array}{c}7432 \\
(4662)\end{array}$ & $\begin{array}{c}8257 \\
(5337)\end{array}$ & $\begin{array}{l}16407 \\
(9707)\end{array}$ & $\begin{array}{c}9886 \\
(5159)\end{array}$ \\
\hline \multicolumn{6}{|c|}{ Stayers } \\
\hline Low & $\begin{array}{l}1658 \\
(629)\end{array}$ & $\begin{array}{c}3147 \\
(1624)\end{array}$ & $\begin{array}{c}4413 \\
(2058)\end{array}$ & $\begin{array}{c}8038 \\
(4077)\end{array}$ & $\begin{array}{c}3372 \\
(1265)\end{array}$ \\
\hline $2 \mathrm{nd}$ & $\begin{array}{c}2445 \\
(1130)\end{array}$ & $\begin{array}{c}3523 \\
(2137)\end{array}$ & $\begin{array}{c}4717 \\
(2456)\end{array}$ & $\begin{array}{c}7128 \\
(3935)\end{array}$ & $\begin{array}{c}4224 \\
(2089)\end{array}$ \\
\hline $3 r d$ & $\begin{array}{c}2575 \\
(1206)\end{array}$ & $\begin{array}{c}3627 \\
(1990)\end{array}$ & $\begin{array}{c}5127 \\
(2793)\end{array}$ & $\begin{array}{c}7953 \\
(4175)\end{array}$ & $\begin{array}{c}4873 \\
(2406)\end{array}$ \\
\hline 4 th & $\begin{array}{c}3516 \\
(1535)\end{array}$ & $\begin{array}{c}4132 \\
(2005)\end{array}$ & $\begin{array}{c}6185 \\
(3251)\end{array}$ & $\begin{array}{l}11897 \\
(5801)\end{array}$ & $\begin{array}{c}8031 \\
(3510)\end{array}$ \\
\hline Total & $\begin{array}{l}2238 \\
(900)\end{array}$ & $\begin{array}{c}3563 \\
(1926)\end{array}$ & $\begin{array}{c}5191 \\
(2729)\end{array}$ & $\begin{array}{c}9528 \\
(4709)\end{array}$ & $\begin{array}{c}5117 \\
(2195)\end{array}$ \\
\hline
\end{tabular}


Table 2b. Mean (Median) of Absolute Values of Preferred Minus Actual Housing Equity, By Move Status and By Housing Equity and Income Quartiles, Including Disturbance Term.

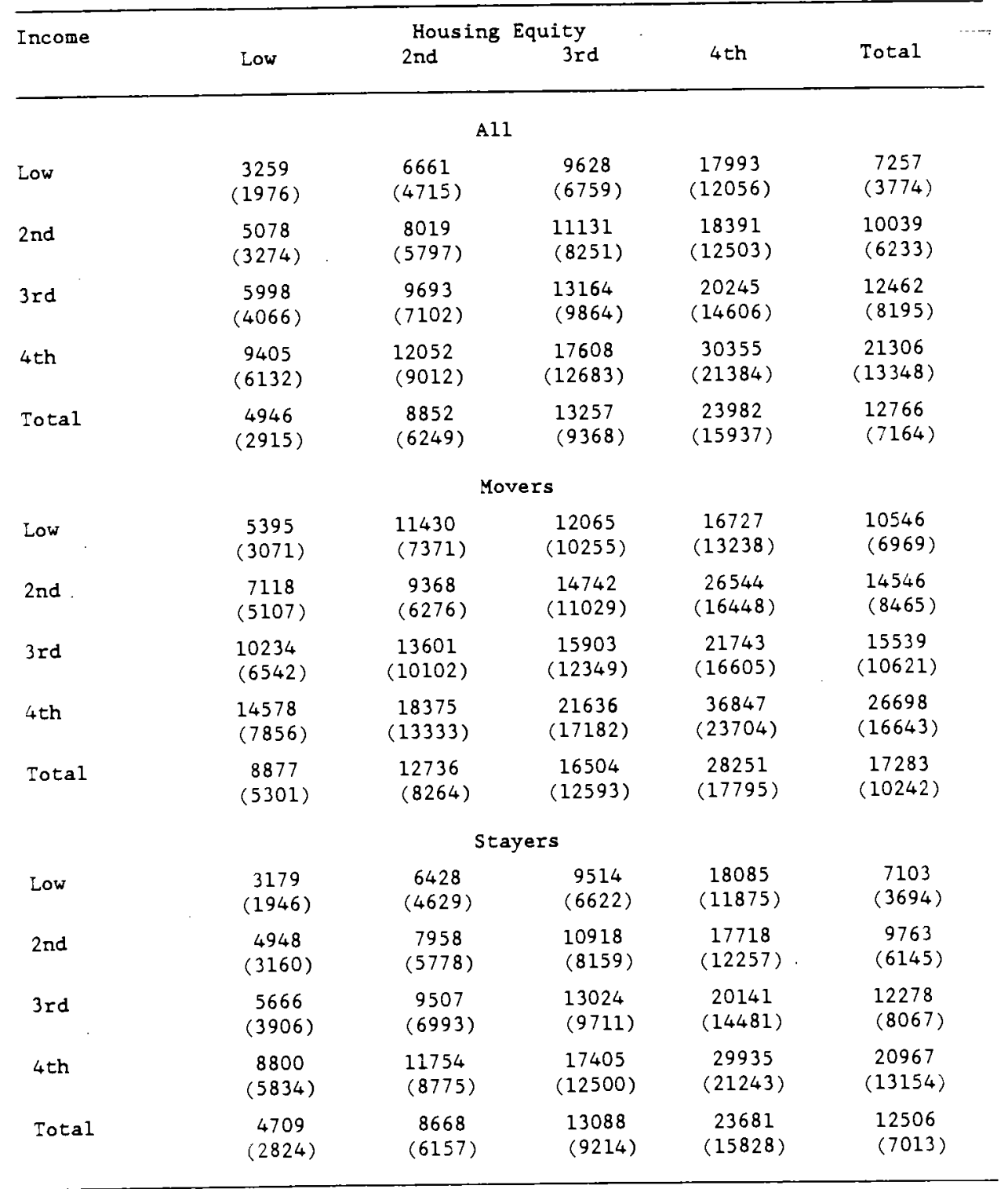


stayers. The difference apparently reflects the fact that, on average, families who move have more to gain from wealth reallocation than families who don't move. That is, to the extent that a reallocation of housing equity is a motivation for moving, the difference should be greater for those who have chosen to move than for those who have not. As emphasized above, however, it is clear that this is not the major reason for moving. The difference increases with both income and housing wealth quartile, especially the latter. The mean difference among movers with high incomes and high housing equity is $\$ 20,069 ;$ the median is $\$ 10,189$. Anong those with low income and low housing equity the mean is only $\$ 3,744$, with a median of only $\$ 2,233$.

Table $2 b$ is analogous to table $2 a$ but the disturbance term in the housing equation is assumed to reflect desired housing choice, instead of a maximization error or deviation from the optimal level. To incorporate the disturbance term, a random draw is made from the estimated error distribution--normal with mean 0 and variance 0.2008 -W--each time that desired housing is predicted. Although this does not affect the expected value of housing equity, since the expected value of $\nu$ is zero, it does affect the absolute values of the deviation. This can be seen by comparing the values in table $2 b$ with those in table $2 a$. For example, the average of the absolute values of the desired change over all families is $\$ 5,377$ when the disturbance term is not accounted for and $\$ 12,766$ when it is.

The values in tables $2 a$ and $2 b$ indicate the change in housing equity that would occur if transaction cost were zero. On average, the desired change in housing equity may be substantial.

But, also on average, the desire is not to reduce, but rather to increase housing equity, as shown in table 3. This table shows the mean (and median) 
Table 3. Mean (and Median) of Preferred Minus Actual Housing Equity, By Move Status and By Housing Equity and Income Quartiles.

\begin{tabular}{|c|c|c|c|c|c|}
\hline & Low & $\begin{array}{l}\text { Income Housing } \\
\text { 2nd }\end{array}$ & $\begin{array}{l}\text { Equity } \\
\text { 3rd }\end{array}$ & 4 th & Total \\
\hline \multicolumn{6}{|c|}{ A11 } \\
\hline Low & $\begin{array}{l}243 \\
(-29)\end{array}$ & $\begin{array}{c}50 \\
(-89)\end{array}$ & $\begin{array}{l}285 \\
(0)\end{array}$ & $\begin{array}{l}-1924 \\
(-1008)\end{array}$ & $\begin{array}{l}-86 \\
(-64)\end{array}$ \\
\hline $2 n d$ & $\begin{array}{l}866 \\
(50)\end{array}$ & $\begin{array}{l}814 \\
(275)\end{array}$ & $\begin{array}{c}191 \\
(427)\end{array}$ & $\begin{array}{l}-225 \\
(-511)\end{array}$ & $\begin{array}{l}468 \\
(30)\end{array}$ \\
\hline $3 \mathrm{rd}$ & $\begin{array}{r}1133 \\
(71)\end{array}$ & $\begin{array}{c}897 \\
(205)\end{array}$ & $\begin{array}{l}1323 \\
(275)\end{array}$ & $\begin{array}{c}649 \\
(269)\end{array}$ & $\begin{array}{l}1009 \\
(185)\end{array}$ \\
\hline $4 t h$ & $\begin{array}{l}2497 \\
(674)\end{array}$ & $\begin{array}{l}1923 \\
(552)\end{array}$ & $\begin{array}{l}2438 \\
(819)\end{array}$ & $\begin{array}{l}3940 \\
(915)\end{array}$ & $\begin{array}{l}3007 \\
(721)\end{array}$ \\
\hline Total & $\begin{array}{l}827 \\
(24)\end{array}$ & $\begin{array}{c}835 \\
(199)\end{array}$ & $\begin{array}{l}1165 \\
(221)\end{array}$ & $\begin{array}{l}1569 \\
(151)\end{array}$ & $\begin{array}{l}1010 \\
(106)\end{array}$ \\
\hline \multicolumn{6}{|c|}{ Movers } \\
\hline Low & $\begin{array}{l}2054 \\
(1048)\end{array}$ & $\begin{array}{l}3406 \\
(269)\end{array}$ & $\begin{array}{c}718 \\
(-2567)\end{array}$ & $\begin{array}{l}-2815 \\
(-2912)\end{array}$ & $\begin{array}{l}1210 \\
(357)\end{array}$ \\
\hline $2 n d$ & $\begin{array}{l}2812 \\
(906)\end{array}$ & $\begin{array}{l}2647 \\
(364)\end{array}$ & $\begin{array}{l}2655 \\
(-524)\end{array}$ & $\begin{array}{c}-833 \\
(-3840)\end{array}$ & $\begin{array}{l}1775 \\
(37)\end{array}$ \\
\hline $3 \mathrm{rd}$ & $\begin{array}{c}4834 \\
(2041)\end{array}$ & $\begin{array}{l}2586 \\
(794)\end{array}$ & $\begin{array}{c}2976 \\
(1754)\end{array}$ & $\begin{array}{l}-1566 \\
(-1487)\end{array}$ & $\begin{array}{l}2127 \\
(810)\end{array}$ \\
\hline 4 th & $\begin{array}{c}7625 \\
(2627)\end{array}$ & $\begin{array}{c}5328 \\
(4868)\end{array}$ & $\begin{array}{c}4310 \\
(1194)\end{array}$ & $\begin{array}{c}9337 \\
(4405)\end{array}$ & $\begin{array}{c}7326 \\
(3109)\end{array}$ \\
\hline Total & $\begin{array}{c}4044 \\
(1324)\end{array}$ & $\begin{array}{l}3321 \\
(704)\end{array}$ & $\begin{array}{l}2877 \\
(930)\end{array}$ & $\begin{array}{c}2822 \\
(-795)\end{array}$ & $\begin{array}{l}3258 \\
(854)\end{array}$ \\
\hline \multicolumn{6}{|c|}{ Stayers } \\
\hline Low & $\begin{array}{c}176 \\
(-39)\end{array}$ & $\begin{array}{l}-114 \\
(-94)\end{array}$ & $\begin{array}{r}264 \\
(2)\end{array}$ & $\begin{array}{l}-1860 \\
(-939)\end{array}$ & $\begin{array}{l}-147 \\
(-67)\end{array}$ \\
\hline $2 n d$ & $\begin{array}{l}743 \\
(26)\end{array}$ & $\begin{array}{c}731 \\
(275)\end{array}$ & $\begin{array}{c}46 \\
(-126)\end{array}$ & $\begin{array}{c}-175 \\
(-439)\end{array}$ & $\begin{array}{l}388 \\
(30)\end{array}$ \\
\hline $3 \mathrm{rd}$ & $\begin{array}{l}843 \\
(50)\end{array}$ & $\begin{array}{c}817 \\
(183)\end{array}$ & $\begin{array}{l}1238 \\
(230)\end{array}$ & $\begin{array}{c}803 \\
(338)\end{array}$ & $\begin{array}{c}943 \\
(176)\end{array}$ \\
\hline 4 th & $\begin{array}{l}1897 \\
(450)\end{array}$ & $\begin{array}{l}1762 \\
(479)\end{array}$ & $\begin{array}{l}2343 \\
(801)\end{array}$ & $\begin{array}{l}3590 \\
(770)\end{array}$ & $\begin{array}{l}2736 \\
(619)\end{array}$ \\
\hline Total & $\begin{array}{c}633 \\
(5)\end{array}$ & $\begin{array}{c}718 \\
(176)\end{array}$ & $\begin{array}{l}1076 \\
(207)\end{array}$ & $\begin{array}{l}1481 \\
(185)\end{array}$ & $\begin{array}{l}975 \\
(89)\end{array}$ \\
\hline
\end{tabular}


difference between desired and existing housing equity, again by housing equity and income, and for movers and for stayers. This table indicates the housing choices that families would make were there no moving transaction costs and all families chose housing equity to optimize the allocation of wealth between housing and other assets. The average difference is $\$ 1,010$ and the median difference is $\$ 106$. Families with low income and high housing wealth would like to reduce housing equity, but those with high income and low housing equity would like to allocate more wealth to housing.

The predicted mean increase for movers is $\$ 3,258$; the median is $\$ 854$. Like the predictions for all households together, those for movers show some reallocations that increase housing equity and others that reduce it. On average, the increases outweigh the reductions. The results in the second panel of the table are very similar in pattern to the findings reported in Venti and Wise [1987], although the magnitudes are smaller here. 12 The mean predicted change in the housing equity of stayers, were they to move, is $\$ 975$, with a median of $\$ 89$. Comparison of the panels for movers and for stayers shows that the predicted changes within the cells are typically greater for movers than for stayers.

The average of predicted percentage differences between actual and desired housing equity are shown in table 4. Two features of the table stand

${ }^{12}$ The earlier results were actual changes in housing equity among movers by housing equity and income quartile, after controlling for age, calendar year, children, and changes in retirement, health, or marital status. A correction was also made for reporting errors. The predictions here may provide more accurate information because the continuous functional form does not allow measurement error--which would be most prevalent among families who enter the upper right and the lower left portions of the table--to exert as large a force on the results as the dummy variable specification used in our earlier paper. It could also be that the specification used here does not fit the data as well as flexible form used there. 
Table 4. Mean (and Median) Percent Difference Between Actual and Preferred housing Equity, By Move Status and by Housing Equity and Income Quartiles.

\begin{tabular}{|c|c|c|c|c|c|}
\hline & Low & $\begin{array}{c}\text { Income } \\
\text { 2nd }\end{array}$ & $\begin{array}{c}\text { Equity } \\
3 \text { rd }\end{array}$ & 4th & Total. \\
\hline \multicolumn{6}{|c|}{ All } \\
\hline Low & $\begin{array}{c}3.4 \\
(-0.4)\end{array}$ & $\begin{array}{c}0.3 \\
(-0.5)\end{array}$ & $\begin{array}{c}0.9 \\
(0.0)\end{array}$ & $\begin{array}{c}-3.3 \\
(-1.9)\end{array}$ & $\begin{array}{c}1.3 \\
(-0.5)\end{array}$ \\
\hline 2nd & $\begin{array}{l}10.4 \\
(0.5)\end{array}$ & $\begin{array}{l}4.1 \\
(1.3)\end{array}$ & $\begin{array}{c}0.7 \\
(-0.4)\end{array}$ & $\begin{array}{c}0.0 \\
(-1.0)\end{array}$ & $\begin{array}{c}4.2 \\
(0.2)\end{array}$ \\
\hline $3 \mathrm{rd}$ & $\begin{array}{l}10.9 \\
(0.8)\end{array}$ & $\begin{array}{c}4.3 \\
(0.9)\end{array}$ & $\begin{array}{c}4.1 \\
(0.9)\end{array}$ & $\begin{array}{c}1.3 \\
(0.5)\end{array}$ & $\begin{array}{c}4.8 \\
(0.8)\end{array}$ \\
\hline 4 th & $\begin{array}{l}24.9 \\
(5.9)\end{array}$ & $\begin{array}{c}8.8 \\
(2.5)\end{array}$ & $\begin{array}{c}7.5 \\
(2.6)\end{array}$ & $\begin{array}{l}7.0 \\
(1.5)\end{array}$ & $\begin{array}{c}9.4 \\
(2.2)\end{array}$ \\
\hline Total & $\begin{array}{c}9.1 \\
(0.3)\end{array}$ & $\begin{array}{c}4.0 \\
(0.9)\end{array}$ & $\begin{array}{c}3.6 \\
(0.7)\end{array}$ & $\begin{array}{c}2.9 \\
(0.3)\end{array}$ & $\begin{array}{c}4.9 \\
(0.6)\end{array}$ \\
\hline \multicolumn{6}{|c|}{ Movers } \\
\hline low & $\begin{array}{c}28.2 \\
(18.2)\end{array}$ & $\begin{array}{l}17.9 \\
(1.2)\end{array}$ & $\begin{array}{c}2.2 \\
(-7.2)\end{array}$ & $\begin{array}{c}-3.5 \\
(-6.9)\end{array}$ & $\begin{array}{l}14.3 \\
(2.2)\end{array}$ \\
\hline 2 nd & $\begin{array}{c}47.2 \\
(13.5)\end{array}$ & $\begin{array}{l}14.4 \\
(1.8)\end{array}$ & $\begin{array}{c}8.3 \\
(-1.7)\end{array}$ & $\begin{array}{c}1.1 \\
(-8.7)\end{array}$ & $\begin{array}{l}18.9 \\
(0.2)\end{array}$ \\
\hline $3 r d$ & $\begin{array}{c}44.3 \\
(17.6)\end{array}$ & $\begin{array}{l}12.4 \\
(3.7)\end{array}$ & $\begin{array}{c}9.1 \\
(5.4)\end{array}$ & $\begin{array}{c}-0.7 \\
(-3.6)\end{array}$ & $\begin{array}{l}16.1 \\
(2.8)\end{array}$ \\
\hline 4th & $\begin{array}{c}71.9 \\
(35.5)\end{array}$ & $\begin{array}{c}26.9 \\
(23.0)\end{array}$ & $\begin{array}{l}12.0 \\
(3.8)\end{array}$ & $\begin{array}{l}18.7 \\
(8.0)\end{array}$ & $\begin{array}{c}28.2 \\
(11.1)\end{array}$ \\
\hline Total & $\begin{array}{c}46.2 \\
(18.8)\end{array}$ & $\begin{array}{l}17.0 \\
(3.4)\end{array}$ & $\begin{array}{c}8.5 \\
(2.8)\end{array}$ & $\begin{array}{c}7.2 \\
(-1.4)\end{array}$ & $\begin{array}{l}19.7 \\
(3.8)\end{array}$ \\
\hline \multicolumn{6}{|c|}{ Stayers } \\
\hline Low & $\begin{array}{c}2.5 \\
(-0.5)\end{array}$ & $\begin{array}{l}-0.5 \\
(-0.5)\end{array}$ & $\begin{array}{c}0.8 \\
(0.0)\end{array}$ & $\begin{array}{c}-3.3 \\
(-1.8)\end{array}$ & $\begin{array}{c}0.7 \\
(-0.6)\end{array}$ \\
\hline 2nd & $\begin{array}{c}8.1 \\
(0.3)\end{array}$ & $\begin{array}{l}3.6 \\
(1.3)\end{array}$ & $\begin{array}{c}0.3 \\
(-0.3)\end{array}$ & $\begin{array}{c}-0.1 \\
(-0.8)\end{array}$ & $\begin{array}{c}3.3 \\
(0.1)\end{array}$ \\
\hline $3 r d$ & $\begin{array}{c}8.3 \\
(0.5)\end{array}$ & $\begin{array}{c}3.9 \\
(0.9)\end{array}$ & $\begin{array}{c}3.8 \\
(0.7)\end{array}$ & $\begin{array}{c}1.5 \\
(0.6)\end{array}$ & $\begin{array}{c}4.2 \\
(0.8)\end{array}$ \\
\hline 4 th & $\begin{array}{l}19.4 \\
(4.3)\end{array}$ & $\begin{array}{l}8.0 \\
(2.2)\end{array}$ & $\begin{array}{c}7.3 \\
(2.5)\end{array}$ & $\begin{array}{c}6.2 \\
(1.3)\end{array}$ & $\begin{array}{c}8.2 \\
(2.0)\end{array}$ \\
\hline Total & $\begin{array}{c}6.8 \\
(0.1)\end{array}$ & $\begin{array}{l}3.4 \\
(0.9)\end{array}$ & $\begin{array}{c}3.4 \\
(0.7)\end{array}$ & $\begin{array}{c}2.6 \\
(0.4)\end{array}$ & $\begin{array}{c}4.1 \\
(0.5)\end{array}$ \\
\hline
\end{tabular}


out. The desired changes are positive on average and are greater for movers than for stayers. And, the desired increases are much greater for families with high income and low housing wealth than for families with low income and high housing equity. This pattern is especially evident among movers. On average movers with high income and low housing equity would like to increase housing equity by 72 percent; the average mover with low income and high housing equity would like to reduce housing equity by only 3.5 percent. Were there no moving transaction costs, and all families moved to optimize the allocation of wealth between housing and other assets, housing equity would increase by 4.9 percent on average; the typical family would not change housing equity, as indicated by the median percent change of 0.6 percent.

\section{Summary and Conclustons}

Mobility among elderly families is very low. Approximately 8 percent of RHS homeowners move during a two-year period. The percent increases very substantially, to about 15 percent, at the time of precipitating shocks like change in marital status or retirement. Thus most elderly are apparently reluctant to move. In our analysis this is reflected in large transaction costs of moving. The analysis emphasizes the potential gain in utility to be had by moving and the resulting opportunity to reallocate wealth between housing and other assets, under the presumption that many elderly would like to withdraw wealth from housing to finance current consumption of other types. This potential gain is very sma11, however, for most elderly. Thus relative to the potential gain from a reallocation of wealth, the transaction costs of moving are large. 
Nonetheless, the transaction costs evidently have very little affect on the housing equity of the elderly. The evidence suggests that although some elderly would make substantial changes in housing equity were they to choose.....new housing, some would choose to add to housing wealth and others to reduce it. On balance, were all elderly to move and choose optimal levels of housing equity, the amount of housing equity would be increased slightly. Thus the results reinforce our earlier findings, and those of Feinstein and McFadden [1988]. Most elderly are not liquidity constrained. And contrary to standard formulations of the life cycle hypothesis, the typical elderly family has no desire to reduce housing equity. This is true even among families with low total wealth, for whom housing equity is a large fraction of total wealth. The desired reduction of housing equity is largest among families with low income and high housing wealth, but even in this case the desired reductions are rather small. And these desired reductions are more than offset by the desired increases of other families, especially those with high income and 10w housing wealth.

The evidence of high moving transaction costs, however, suggests that some families may be prevented by such costs from moving, even though they would like to reduce housing equity. It is for these families that reverse annuity mortgages would apparently be most beneficial. Limited demand, though, may explain the absence of an active market for such financial instruments. 
Appendix: Selection of estimation sample and variable definitions.

The estimates are based on data from the Retirement History Survey (RHS). The survey covered families headed by persons between ages 58 and 63 in 1969 . The families were interviewed every two years between 1969 and 1979; there were six waves altogether. The initial sample contained slightly over 11,000 families. Over 8,000 families were interviewed in the last survey in 1979.

To obtain the sample for this paper we began with all families who owned homes in 1969. A family was omitted from the sample if the first move was to a rental unit, or if data used in the analysis (other than housing wealth) were missing in any year prior to the first move. The remaining sample consisted of 4106 families. In addition, housing equity was sometimes missing or misreported. In some cases housing equity was not reported in one or more years; in other cases it was apparently either incorrectly reported or incorrectly coded in one or more years. This latter problem is clearly evident in the tremendous year to year variation in housing equity. In our model a large error in reported housing equity for a family that doesn't move in a given interval means that the family must be dropped from the sample. This is because a family, at each point in time, must choose between its current level of housing equity (inherited from the previous period) and the optimal allocation of housing wealth. If housing equity is incorrecty reported to be unusually high in period $t$, then in some cases housing equity in period $t$ will exceed total wealth in period $t+1$. Unless nonhousing wealth is negative or housing values dropped sharply between periods $t$ and $t+1$, such cases reflect error in year to year reported housing equity. Instead of deleting all such cases from the sample, the median of housing equity (in 1979 dollars) over all periods prior to a move is used as the measure of housing 
equity in each period that the family does not move. If a family moves, the median represents the equity of the old unit; the equity of the new unit is the reported amount. The final sample includes 3423 families.

Initial estimates were obtained using reported housing equity throughout. This meant that a disproportionate number of families with low housing equity and low total wealth were deleted from the sample. In fact, the central conclusions of the paper are not affected by the sample selection procedure, although individual estimates are.

The definitions of most of the variables are straightforward. Housing equity is the market value of the house less mortgage and other debt on the house. Nonhousing wealth includes real property (less debt), motor vehicles (less debt), savings bonds, corporate stocks and bonds, checking accounts, savings accounts, and the face value of life insurance. Total wealth is the sum of housing and nonhousing wealth. The changes in health, retirement, and family status pertain to the two-year intervals between surveys. 


\section{References}

Butler, J.S. and R. Moffitt. 1982. "A Computationally Efficient Quadrature Procedure for the One-Factor Multinomial Probit Mode1," in Econometrica, Vo1. 50, No. 3, May.

Feinstein, J. and D. McFadden. 1988. "The Dynamics of Housing Demand by the Elderly: Wealth, Cash Flow, and Demographic Effects." NBER Working Paper No. 2471. Forthcoming in D. Wise (ed.) The Economics of Aging.

University of Chicago Press.

Henderson, J.V. and Y.M. Ioannides. 1983. "A Model of Housing Tenure Choice," in American Economic Review, Vol. 73, pp. 98-113.

. 1987, "Owner Occupancy: Investment Vs. Consumption Denand," in Journal of Urban Economics, Vo1. 21, PP. 228-241.

Merri11, S. 1984. "Home Equity and the Elderly," in H. Aaron and G. Burtless (eds.) Retirement and Economic Behavior. Brookings Institution. Venti, S.F. and D.A. Wise. 1984. "Moving and Housing Expenditure:

Transaction Costs and Disequilibrium," in Joumal of Public Economics, Vo1. 23, Pp. $207-243$.

1988. "Aging, Moving, and Housing Wealth." NBER Working Paper No. 2324. Forthcoming in D. Wise (ed.) The Economics of Aging. University of Chicago Press. 